\title{
A New Approach to the Management of Functional Dyspepsia: Results of a Multicenter, Randomized, Double-blind, Placebo-controlled Trial
}

\section{Vladimir T. Ivashkin}

I.M. Sechenov First Moscow State Medical University (Sechenov University)

\section{Yulia O. Shulpekova}

I.M. Sechenov First Moscow State Medical University (Sechenov University)

Igor V. Maev

Moscow State University of Medicine and Dentistry named after A.I. Yevdokimov

Vladimir B. Grinevich

Kirov Military Medical Academy

Igor B. Khlynov

Ural State Medical University

\section{Yury G. Shvarts}

Saratov State Medical University

Alexey B. Glazunov ( $\nabla$ makarovaea@materiamedica.ru )

Pirogov Russian National Research Medical University

\section{Research Article}

Keywords: Functional dyspepsia, clinical trial, efficacy assessment, safety profile

Posted Date: October 5th, 2021

DOl: https://doi.org/10.21203/rs.3.rs-753161/v1

License: (9) (i) This work is licensed under a Creative Commons Attribution 4.0 International License. Read Full License 


\section{Abstract}

The aim of the study was to evaluate the efficacy and safety of Kolofort (a complex medicine containing technologically processed forms of antibodies to S-100 protein, tumor necrosis factor-a and histamine) in the management of functional dyspepsia (FD) in outpatient clinical practice.

Methods: 309 outpatients at the age of 18-45 in whom functional dyspepsia was diagnosed according to the Rome IV criteria were enrolled in a multicenter, double-blind, placebo-controlled, randomized clinical trial. Patients were randomized in two groups receiving Kolofort or Placebo 2 tablets tid for 8 weeks. The primary endpoint of the study was a change in the FD symptoms severity score according to the Gastrointestinal symptom score (GIS) at week 8 . The demand in accessory medications was also assessed.

Results: at week 8 the reduction in GIS sum score was observed in Kolofort group and Placebo group (by $7.2 \pm 3.3[7.2 \pm 3.4]$ and $6.3 \pm 4.6[6.2 \pm 4.5]$, respectively, $p=0.041$ [0.039]). The proportion of cases with GIS score reduction by $\geq 4$ was $88.1 \%$ [88.6\%] and $79.1 \%$ [79.6\%] in Kolofort group and Placebo group, respectively ( $p=0.051[p=0.046])$. None of the patients in Kolofort group had experienced progression of FD symptoms or required additional therapy. 29 AEs were recorded including 16 cases in 13 (8.6\%) patients in Kolofort group and 13 AEs in 12 (7.6\%) patients in Placebo group.

Conclusion: the clinical trial demonstrates the positive effect of Kolofort in FD with a favorable safety profile.

\section{Background}

The prevalence of functional dyspepsia (FD) in adults is about 10\% [1]. FD is considered to be a gut-brain axis disorder, with the development of visceral hypersensitivity and impaired gastroduodenal motility and multifactorial pathogenesis [2]. Pathogenetic association between FD and chronic gastritis remains to be studied more profoundly. Chronic gastritis can be found in a large proportion of patients with dyspeptic symptoms [3]. At the same time morphological features of chronic gastritis are not always associated with dyspepsia and the pathogenetic treatment of chronic inflammation of gastric mucosa is not always accompanied by symptomatic relief [4]. Whilst dyspepsia develop in Helicobacter pylori (H. pylori)associated chronic gastritis it should be categorized as " $H$. pylori-associated dyspepsia" but not as a primary FD [5-7].

Current algorithms for FD management include lifestyle modification, medications and psychotherapy in selected cases [8]. Drug therapy implies antisecretory agents, prokinetics and herbal preparations which normalize intestinal motility and visceral sensitivity. Antidepressants can be recommended in intractable cases $[9,10]$. Moreover it's worth noticing that polypharmacy increases the risk of adverse events. The attempts to create complex acting medications for the treatment of FD is ongoing. 
Kolofort (OOO "NPF "MATERIA MEDICA HOLDING") can be considered as one of the approaches for the treatment of FD. The drug preparation Kolofort was registered in Russian Federation in 01/07/2010 and approved for irritable bowel disease treatment (in accordance with the local registration number ЛСР-006226/1). The active components of Kolofort are technologically processed (highly diluted) affinity-purified polyclonal antibodies to TNF-a (anti-TNFa), to brain-specific protein S-100 (anti-S100), and to histamine (anti-H). Kolofort can exert a complex effect on the central and peripheral components of visceral hypersensitivity and gut motility and hence can represent a complex approach for FD treatment [11].

Clinical and experimental studies demonstrate the reduction in colonic hypersensitivity to stretching, improvement in impaired gastrointestinal motility and stomach evacuation, relief of abdominal distention and pain in the course of Kolofort treatment. Kolofort exerts antispasmodic action decreasing gastrointestinal tone and intraluminal pressure, normalizing defecation and stool consistency and relieving urgency, tenesmus, excessive straining and sensation of incomplete evacuation $[12,13]$.

It was shown recently that high dilutions of any substances obtained using a technological process that is a repeated dilution of the source substance in combination with external physical impact have the ability to modify the activity of the source substance or its target by changing the conformation of the molecule $[14,15,16,17]$.

Several studies suggested that the source substance molecules could be still present in high dilutions [18, $19,20,21]$. The modifying effect of high dilution has been repeatedly demonstrated in various experimental models, but its physical mechanisms need to be studied with special physical and chemical methods $[22,23,24,25]$. The technology of high dilutions has been gradually introduced into practice and several medications have been created based on high dilutions of antibodies $[26,27,28,29,30,31,32]$. Their efficacy and safety have been proven in numerous studies performed according to the principles of evidence-based medicine [33, 34, 35, 36, 37].

The aim of this study was to obtain additional data on the efficacy and safety of Kolofort in the treatment of FD.

\section{Materials And Methods}

The study was designed as a multicenter, double-blind, placebo-controlled, randomized clinical trial in parallel groups. The study was conducted during the period from June 2017 to January 2020 at 39 clinical centers in the Russian Federation in accordance with national requirements. The study was permitted by the Ministry of Health and approved by the central and local ethical committees. The registration number at ClinicalTrials.gov ID: NCT03119766. The first patient was included in the clinical trial on 28/06/2017 year. The first posted date on ClinicalTrials.gov - 19/04/2017 year.

Outpatients 18-45 years of age were enrolled in the study. In all cases functional dyspepsia was diagnosed according to the Rome IV criteria with the severity of symptoms not less than 6 points based 
on the GIS (Gastrointestinal Symptom Score) and negative results of endoscopic express-test for H. pylori infection. Also, the data for the Nepean Dyspepsia Index (NDI) assessing the impairment of health-related quality of life in dyspepsia, the Short Form Health Survey (SF-36) and the Clinical Global ImpressionEfficacy Index (CGI-EI) were collected in the course of the study. The stable persistence or progression of FD symptoms making it necessary to prescribe standard therapy (proton pump inhibitors, prokinetics, antispasmodics) were defined as the "inefficacy of study therapy".

The primary endpoint of the study was a change in FD symptoms severity according to the GIS scale at week 8. As secondary endpoints were assessed: the percentage of patients with reduced severity of FD symptoms according to the GIS sum score after 8 weeks of treatment, a change in the NDI index at week 8 , a change in the quality of life according to SF-36 at week 8, the percentage of patients withdrawn from the study prematurely due to ineffectiveness of therapy, CGI-El at week 8.

At the screening visit (Visit 1, Days -14 -(-1 day), complaints, GIS score, medical and drug history, concomitant diseases and physical parameters were registered.

Abdominal ultrasound, esophagogastroduodenoscopy with H. pylori test were performed to exclude other possible causes of dyspeptic symptoms. Urinary express test for pregnancy was performed in women of childbearing potential. At Visit 2 (Day 1 ) the patients who met all the inclusion criteria and none of the exclusion criteria were randomized by automated interactive voice system to Kolofort group (received 2 tablets of Kolofort bid for 8 weeks) or Placebo group (received 2 tablets of Placebo bid for 8 weeks). In

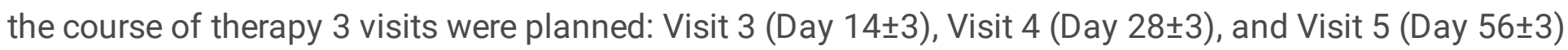
to assess complaints, physical data, concomitant therapy, patient's compliance and safety of the treatment. At Visits 2, 4, and 5 data for GIS and NDI were collected. SF-36 was filled in on Visits 2 and 5 and the CGI-El questionnaire was assessed at the end of the study. The duration of the follow up period was up to 10 weeks.

The following medications were prohibited a month before and during the period of the study: acidsuppressive agents and antacids, drugs for functional gastrointestinal disorders (except Kolofort produced by "NPF "MATERIA MEDICA HOLDING"), histamine receptor blockers, steroids (except topical and corticosteroids for inhalation), non-steroidal anti-inflammatory drugs, anti-rheumatic drugs, analgesics, anticancer drugs, immunostimulants, immunosuppressants, immune sera and immunoglobulins, vaccines, calcium supplements, iron supplements, zinc supplements, potassium supplements, and antimicrobial drugs of systemic action. Antispasmodic drotaverine in a total dose not exceeding $640 \mathrm{mg}$ during the treatment period was allowed. The study participants were warned to use reliable contraception methods.

Treatment allocation to Kolofort or Placebo was double-blind. Kolofort tablets and Placebo had the same organoleptic characteristics. The batch number, package number, number of the study protocol, number of tablets in the package, and route of administration were indicated on the cardboard pack. 
The following assumptions were taken into account when calculating the sample size: the power of statistical criteria $80 \%$, the probability of type I error " $a$ " less than $5 \%$, statistical criteria for intergroup comparisons were bilateral; the sample size was based on assumptions about expected effect, declared in the main performance criteria of this protocol; the ratio between the sample size of Kolofort group and Placebo group was 1:1. The size of each group was assumed to be 129 . Given the possible $30 \%$ dropout during the study, it was necessary to enroll at least 185 patients in each group. For analysis of continuous variables Student's t-test, non-parametric Wilcoxon test, and median analysis were used. Visual analysis of the model QQ plot was used for assessment of normality. Two-factor analysis of variance ("Group" and "Visit") was used to compare changes in parameters. A single-factor analysis of variance was used with the "Group" factor. Frequency analysis of difference between two groups proportions was performed using Fisher's exact test. Data processing and all statistical calculations were performed using the statistical package SAS-9.4. The results of the ITT and [PP] efficacy analyses are presented.

\section{Results}

\section{Patient flow}

370 patients who had signed the informed consent were assessed for eligibility criteria (Figure 1). 61 patients were withdrawn at screening visit as they didn't completely meet the inclusion criteria or met the exclusion criteria. 309 patients were randomized into two groups $(n=151$, Kolofort group; $n=158$, Placebo group).

282 patients ( $n=140$, Kolofort group; $n=142$, Placebo group) completed therapy per protocol. 27 cases ( $n=11$, Kolofort group; $n=16$, Placebo group) were excluded from PP analysis due to some deviations from protocol requirements.

\section{Patient demographics}

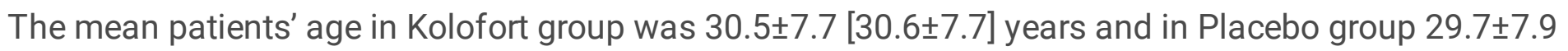
[29.9 \pm 7.8$]$ years $(p=0.3035[p=0.4033])$. Females predominated in both groups $(69.5[69.3] \%$ and 69.6 [67.6] \%). Males proportions were $30.5[30.7] \%$ and 30.4 [32.4] \%, respectively ( $p=0.9872[p=0.7615])$.

There were no other significant differences in demographic characteristics between the two groups. At the screening visit all the patients had negative results of $H$. pylori test. The initial GIS score had no significant difference between the groups, reaching a total of $10.4 \pm 3.5[10.4 \pm 3.4]$ points in Kolofort group and 10.1 $\pm 4.0[10.0 \pm 4.0]$ points in Placebo group $(p=0.1209[p=0.0763])$.

$47.7 \%$ [47.1\%] of patients in Kolofort group and 48.1\% [47.9\%] in Placebo group had various comorbidities $(p=0.164[p=0.400])$. Diseases of digestive system or indirectly related to digestion (chronic gastritis, dental caries, umbilical hernia, diverticulum of the intestine, etc.) were registered in $23.2 \%$ [ 22.9 $\%$ ] cases in Kolofort group and in 25.3\% [25.4\%] cases in Placebo group. Respiratory system disorders (asthma, chronic bronchitis, vasomotor rhinitis, etc.) were noted in $2.6 \%$ [2.9\%] and 3.8\% [3.5\%] cases, and 
previous surgery (appendectomy, cesarean section, cauterization of the cervix, rhinoplasty, phlebectomy, etc.) - in 3.3\% [3.6\%] and 4.4\% [4.2\%] cases, respectively. Other diseases were registered in a small percentage of patients in both groups.

The most common concomitant pathology was $\mathrm{H}$. pylori-negative chronic gastritis which was detected in $21.2 \%$ [20.7\%] of patients in Kolofort group and in $23.4 \%$ [23.2\%] of patients in Placebo group.

Concomitant therapy was registered in $9.9 \%$ [9.3\%] of cases in Kolofort group and $13.3 \%$ [10.6\%] of cases in Placebo group $(p=0.665[p=0.949])$ and included sex hormones and their modulators, mainly contraceptives (3.3\% [3.6\%] and 3.8\% [3.5\%] in both groups, respectively, $p=1.00[p=1.00])$. Other concomitant medications were rare. Fisher's exact test showed no significant difference in co-morbidities and concomitant therapy in both ITT and PP analyses.

Three patients (1.98\% [2.1\%]) in Kolofort group and 8 patients (5.06\% [4.4\%]) in Placebo group received medication for functional gastrointestinal disorders: drotaverine in allowed doses in 10 cases and mebeverine considered as a prohibited drug in 1 case (this patient was withdrawn from the study). Z-test showed no significant difference between groups in ITT analysis $(p=0.05)$.

The patients' compliance was close to $100 \%$ and did not have significant difference between groups on Visit 3, Visit 4 and Visit 5 ( $p=0.9130$ [ $p=0.7537] ; p=0.4282$ [ $p=0.6852] ; p=0.3944[p=0.2412])$.

\section{Efficacy assessment}

By the end of week 8 a reduced severity of FD symptoms was observed according to the GIS score in both groups (by 7.2 $\pm 3.3[7.2 \pm 3.4]$ in Kolofort group and by $6.3 \pm 4.6[6.2 \pm 4.5]$ in Placebo group, respectively, $\mathrm{p}=0.041[0.039])($ Table 1).

\section{Table 1}

Change in the severity of FD symptoms according to the GIS sum score after 8 weeks of treatment 
Index

ITT analysis

PP analysis

\begin{tabular}{|c|c|c|c|c|}
\hline & $\begin{array}{l}\text { Kolofort } \\
\text { group } \\
\mathrm{N}=151\end{array}$ & $\begin{array}{l}\text { Placebo } \\
\text { group } \\
\mathrm{N}=158\end{array}$ & $\begin{array}{l}\text { Kolofort } \\
\text { group } \\
\mathrm{N}=140\end{array}$ & $\begin{array}{l}\text { Placebo } \\
\text { group } \\
N=142\end{array}$ \\
\hline Mean $\pm S D$ & $7.2 \pm 3.3$ & $6.3 \pm 4.6$ & $7.2 \pm 3.4$ & $6.2 \pm 4.5$ \\
\hline Median & 7 & 6 & 7 & 6 \\
\hline Min and Max & $1-18$ & $-12-33$ & $1-18$ & $-12-33$ \\
\hline Lowest and highest quartile (Q1 $1-\mathrm{Q} \underline{3})$. & $5-9$ & $4-8$ & $5-9$ & $4-8$ \\
\hline $95 \% \mathrm{Cl}$ & {$[6.4,8.0]$} & {$[5.5,7.1]$} & {$[6.4,8.0]$} & {$[5.5,7.1]$} \\
\hline $\begin{array}{l}\text { "Kolofort - Placebo" difference in means } \\
95 \% \mathrm{Cl}\end{array}$ & \multicolumn{2}{|c|}{$0.94[0.04-1.85]$} & \multicolumn{2}{|c|}{$0.98[0.05-1.92]$} \\
\hline P-value & \multicolumn{2}{|c|}{$\begin{array}{l}\text { "Group" factor } \\
\mathrm{P}=0.041\end{array}$} & \multicolumn{2}{|c|}{$\begin{array}{l}\text { "Group" factor } \\
P=0.039\end{array}$} \\
\hline
\end{tabular}

Notes. Comparison of the average GIS scores was carried out using analysis of variance with fixed "Group" factor. Yeo-Johnson $(\lambda=0)$ data transformation was used for the two-factor ("Group" and "Visit" factors) analysis of variance, leading to normalization of distribution of residuals. $95 \% \mathrm{Cl}-95 \%$ confidence interval.

The regression of FD symptoms according to the GIS scale at week 8 was analyzed by its degree ("category», with decrease by 1, 2, 3, 4 or more points). In Kolofort group the proportion of patients with reduced severity of FD symptoms by $\geq 1$ points was $99.3 \%[100.0 \%]$ at week 8 , in Placebo group $-95.6 \%$ $(p=0.067[p=0.122])$.

In the ITT sample the median GIS sum score decreased by 2 points in $96 \%$ of patients in Kolofort group and $89.2 \%$ of patients in Placebo group ( $\mathrm{p}=0.029)$; by $\geq 3$ points in $91.4 \%$ of patients in Kolofort group and $84.8 \%$ of patients in Placebo group $(\mathrm{p}=0.082)$; by $\geq 4$ points in $88.1 \%$ of patients in Kolofort group and $79.1 \%$ of patients in Placebo group $(p=0.046)$.

The initial score of the average NDI index value was 23.5 \pm 7.0 [23.6 \pm 7.0$]$ in Kolofort group and 23.5 \pm 6.9 [23.4 \pm 7.1$]$ points in Placebo group. At week 8 a tendency to reduction in the FD symptom influence on daily activity was seen in the Kolofort group: at weeks 4 and 8 NDI score corresponded to $17.1 \pm 5.6$ [17.1 \pm 5.8$]$ and $14.4 \pm 5.1$ [14.5 \pm 5.2 ] in Kolofort group versus 17.0 \pm 6.0 [17.1 \pm 6.4 ] and 14.9 \pm 6.0 [15.0 \pm 6.2$]$ in Placebo group, respectively. Thus, the total change in NDI score in the course of treatment was $9.1 \pm 7.1$ [9.1 \pm 7.2$]$ in Kolofort group and 8.5 \pm 6.6 [8.5 \pm 6.7$]$ in Placebo group, $p=0.435$ [ $p=0.450$ ] for the "Group" factor.

By the week 8, the median score of the SF-36, demonstrating the physical health component, increased

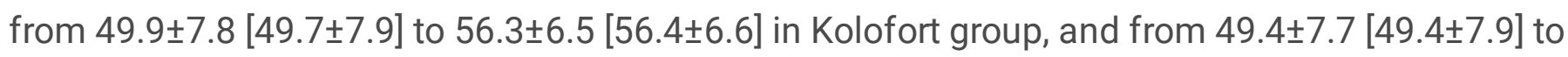
$56.2 \pm 6.3[56.2 \pm 6.5]$ in Placebo group. According to analysis of variance with fixed "Group" factor, the 
median score increased by $6.4 \pm 7.5[6.7 \pm 7.6]$ in Kolofort group and by $6.8 \pm 7.0[6.8 \pm 7.1]$ in Placebo group $(p=0.655[p=0.908])$.

The median score of the SF-36, demonstrating the mental health component, increased from $33.6 \pm 5.7$

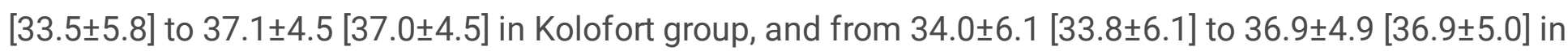
Placebo group. So the change of median score was $3.5 \pm 6.3[3.5 \pm 6.3]$ in Kolofort group and $2.9 \pm 6.6$ $[3.1 \pm 6.6]$ in Placebo group $(p=0.375[p=0.599])$.

None of the patients in Kolofort group had experienced stable persistence or progression of FD symptoms or required additional prohibited therapy throughout 8 weeks of treatment. One patient in Placebo group required additional prohibited therapy for progression of FD symptoms and therefore was withdrawn from the study.

The majority of investigators evaluated the therapeutic effect of Kolofort as "pronounced". The median therapeutic effect score was $2.67 \pm 2.96[2.71 \pm 3.01]$ in Kolofort group and $3.33 \pm 3.49[3.27 \pm 3.49]$ in Placebo group $(p=0.139[p=0.258])$.

According to investigators' opinion, there were no adverse effects in the majority of patients throughout 8 weeks of therapy. According to the CGI-El scale the median score of adverse effects in Kolofort and Placebo groups were $1.09 \pm 0.31[1.08 \pm 0.27]$ and $1.04 \pm 0.19[1.04 \pm 0.20]$, respectively $(p=0.08[p=0.201])$.

According to investigators' estimation the final clinical efficacy index was $3.76 \pm 2.98$ [3.79 \pm 3.04$]$ points in Kolofort group and 4.37 $\pm 3.51[4.31 \pm 3.52]$ points in Placebo group $(p=0.251[p=0.371])$.

The dynamics of FD symptoms in patients with H. pylori-negative chronic gastritis was analyzed separately. Changes in the GIS sum score (the difference between the first and last visits) show the reduction in symptom severity in cases of FD associated with chronic gastritis (Figure 2). The most significant changes were seen for epigastric pain, bloating and early satiety.

\section{Safety assessment}

The safety and tolerability of therapy were evaluated in patients who received at least one dose of Kolofort or Placebo (Safety population, $n=309$ ). The safety of the drug was assessed in terms of adverse events (AEs), their severity and relation to the study drug, outcomes.

Statistical analysis with the Bonferroni correction method showed no influence of Kolofort and Placebo on systolic blood pressure (SBP), diastolic blood pressure (DBP), heart rate, and respiration rate.

In the study 16 AEs were recorded in 13 (8.6\%) patients in Kolofort group and 13 AEs in 12 (7.6\%) patients in Placebo group. Fisher's exact test showed no significant difference in AE rate in both groups $(p=0.836)$. There was no significant difference in the number of patients with AEs with particular MedDRA codes between the two groups. 
Most AEs (7 (4.6\%) cases in Kolofort group and 4 (2.5\%) in Placebo group) were associated with digestive system dysfunction. Gastrointestinal tract hyperkinesia $(n=1)$, diarrhea $(n=1)$, dyspepsia $(n=1)$, constipation $(n=1)$, mouth dryness $(n=2)$, and nausea $(n=1)$ were recorded in Kolofort group; diarrhea $(n=1)$, constipation $(n=2)$, and mouth dryness $(n=1)$ in Placebo group.

In 4 (2.6\%) patients in Kolofort group and $3(1.9 \%)$ patients in Placebo group infections and infestations were detected. Other AEs in Kolofort group included nasopharyngitis $(n=1)$, rhinitis $(n=1),(n=1)$, acute respiratory infection $(n=2)$. In Placebo group acute respiratory infection $(n=1)$, nasopharyngitis $(n=1)$, tonsillitis $(n=1)$, and cystitis $(n=1)$ were detected.

According to investigators' opinion, the cause-effect relationship of AEs with the study drug (Kolofort) was assessed as negative in 10 cases $(n=10 ; 62.5 \%)$, possible in 2 cases $(n=2 ; 12.5 \%)$ and probable in 4 cases $(n=4 ; 25.0 \%)$. No $A E$ with a reliable connection to the study drug was registered. The distribution of AEs according their severity $(p=0.632)$ and a causal relationship with the study drug $(p=0.785)$ did not differ between the groups. No severe AEs were reported throughout the study.

\section{Discussion}

The study demonstrates a significant improvement of FD symptoms (epigastric pain, early satiety, nausea, vomiting, bloating, heartburn/acid belching, feeling of weakness in combination with pain, nausea, and loss of appetite) in the course of 8-week Kolofort therapy. In the subgroup with H. pylorinegative chronic gastritis a distinct trend for FD symptom improvement although not statistically significant is shown.

Kolofort treatment showed no statistically significant impact on the quality of life although a clear positive trend was demonstrated in terms of daily activities. The absence of statistic significance can be explained by the insufficient length of the study since a pronounced residual placebo effect may persist in 8 weeks. A longer study may be needed to assess Kolofort effect on daily activities and quality of life in FD more profoundly. It would be appropriate to accentuate that according to a Cochrane review prokinetics which represent a clear positive effect in many patients with postprandial distress syndrome do not demonstrate the significant impact on the quality of life [38].

In Kolofort group there were no cases of early withdrawal from the study due to therapy ineffectiveness or to prescription of accessory medications for FD prohibited in the protocol. The rate of additional prescriptions for the treatment of functional gastrointestinal symptoms in Kolofort group was 2.7 times lower than in Placebo group, that indirectly indicates its clear influence on the gastrointestinal function.

The study demonstrates the safety of Kolofort in the treatment of FD. No AEs were registered having a clear causative relationship with the studied preparation. No cases of Kolofort incompatibility with other medication were registered, including those used for functional gastrointestinal disorders, bronchial asthma, rhinitis, analgesics, medications affecting renin-angiotensin system, beta-blockers, sex hormones 
and modulators of the reproductive system. The treatment was well-tolerated, with high patients' compliance.

This multicenter, double-blind, placebo-controlled trial had demonstrated the efficacy and safety of Kolofort in FD, including cases of FD in H. pylori-negative chronic gastritis. The therapeutic activity of Kolofort in FD can be attributed to the influence on the mechanisms of inflammation, visceral hypersensitivity and gut-brain axis dysfunction [13]. In an 8-week period the effect of Kolofort can be also implemented through anxiolytic, antispasmodic, anti-inflammatory action and normalization of gastrointestinal motility $[12,13]$. Taking in account the frequent overlap of FD with other functional gastrointestinal disorders (e.g., irritable bowel syndrome) further investigations of Kolofort efficacy seem to be rational $[39,40]$.

Study protocol can be found on ClinicalTrials.gov. Identifier: NCT03119766.

\section{Declarations}

\section{Ethics approval and consent to participate.}

The study protocol was approved by the Ethical Review Committee of Ministry of Health of Russian Federation, extract from the protocol № 141 (14.02.2017). The study was performed according to the Declaration of Helsinki 2013. Written Informed consent was obtained from all individual adult participants included in this study. This manuscript has not been published in whole or in part. All authors have read the manuscript and have agreed that the work is ready for submission and accept responsibility for its contents.

\section{Consent for publication.}

Not applicable.

\section{Availability of data and materials.}

The datasets obtained during this study will be available upon request to the corresponding author.

\section{Competing interests.}

The authors declare that they have no conflict of interest.

\section{Funding.}

Not applicable. 


\section{Authors' contributions:}

V.I., Y.Sh. and A.G. devised the project, the main conceptual ideas and planned the protocol. V.I., Y.Sh., I. M., I. K. were the mail researchers in the cites. Yury S. and A.G wrote the manuscript. Y. Sh. and V. G. developed the theoretical framework and proposed the discussion section. All authors provided critical feedback and helped shape the research, analysis and manuscript. All authors reviewed the manuscript.

\section{Acknowledgements}

The authors gratefully acknowledge the all participants in the clinical trial.

\section{References}

1. Aziz I, Palsson OS, Törnblom H, Sperber AD, Whitehead WE, Simrén M. Epidemiology, clinical characteristics, and associations for symptom-based Rome IV functional dyspepsia in adults in the USA, Canada, and the UK: a cross-sectional population-based study. Lancet Gastroenterol Hepatol. 2018 Apr; 3(4):252-262.

2. Mukhtar $\mathrm{K}, \mathrm{Nawaz} \mathrm{H}$, Abid S. Functional gastrointestinal disorders and gut-brain axis: What does the future hold? World J Gastroenterol. 2019; 25(5):552-566.

3. Azer SA, Akhondi H. Gastritis. 2020 Jul 6. In: StatPearls [Internet]. Treasure Island (FL): StatPearls Publishing; 2020 Jan-. PMID: 31334970.

4. Warrwewijk C.J., Van Oijen M.G.H., Paloheimo L.I. et al. Influence of gastric mucosal status on successs of stepwise acid suppressive therapy for dyspepsia. Aliment.Pharmacol.Ther. - 2009. Vol.30. - P.82-89.

5. Sugano K., Tack J., Kuipers E. $†$ J. et al. Kyoto global consensus report on Helicobacter pylori gastritis. Gut 2015; 64:133-67.

6. Malfertheiner P., Megraud F., O'Morain C.A. et al. Management of Helicobacter pylori infection - the Maastricht V/Florence Consensus Report. Gut 2016 Oct 4 doi: org/10.1136/gutjnl-2016-312288.

7. Клинические рекомендации Российской гастроэнтерологической ассоциации по диагностике и лечению функциональной диспепсии В.Т. Ивашкин, И.В. Маев, А.А. Шептулин, Т.Л. Лапина, А.С. Трухманов, И.М. Картавенко, В.А. Киприанис, О.З. Охлобыстина. Рос журн гастроэнтерол гепатол колопроктол 2017;27(1).

8. Yamawaki H, Futagami S, Wakabayashi M, et al. Management of functional dyspepsia: state of the art and emerging therapies. Ther Adv Chronic Dis. 2018;9(1):23-32.

9. Sayuk GS, Gyawali CP. Functional Dyspepsia: Diagnostic and Therapeutic Approaches. Drugs. 2020 Sep; 80(13):1319-1336.

10. Luo L, Du L, Shen J, Cen M, Dai N. Benefit of small dose antidepressants for functional dyspepsia: Experience from a tertiary center in eastern China. Medicine (Baltimore). 2019; 98(41):e17501. 
11. Инструкция по медицинскому применению препарата Колофорт ЛП-N (000027) - (PГ-RU).

12. Авалуева Е.Б., Адашева Т.В., Бабаева А.Р., Бурдина Е.Г., Киреева Н.В. Эффективность и безопасность применения Колофорта при синдроме раздраженного кишечника: итоги многоцентрового двойного слепого плацебо-контролируемого рандомизированного клинического исследования. Гастроэнтерология, 2014; 1: 36-43.

13. Эртузун И. А., Зуева Е. П. и др. Экспериментальное изучение «Колофорта» - нового препарата для лечения синдрома раздраженного кишечника и других функциональных заболеваний желудочно-кишечного тракта. Вестник ВолГМУ, 2012; 4 (44):25-27.

14. Петров С.И., Эпштейн О.И. Потенцированные растворы: влияние на сигнал ртути (II) в инверсионной вольтамперометрии. Бюллетень экспериментальной биологии и медицины. 2003. - Прил.1. - С.6-9.

15. Эпштейн О.И. Нейрофизиологические механизмы фармакологических эффектов потенцированных(«гомеопатизированных») антител к мозгоспецифическому белку S-100 // автореф. дисс..... наук. - Томск. - 1999. - 24с.

16. Epstein O. The spatial homeostasis hypothesis. Symmetry. - 2018. - Vol.10(4). - 103. doi:10.3390/sym10040103.

17. Tarasov S.A., Gorbunov E.A., Don E.S., Emelyanova A.G., Kovalchuk A.L., Yanamala N., Schleker A.S.S., Klein-Seetharaman J., Groenestein R., Tafani J-P., van der Meide P., Epstein O.I. Insights into the mechanism of action of highly diluted biologics. The Journal of Immunology. - 2020. - Vol.205, issue 5. - P.1345-1354. doi: 10.4049/jimmunol.2000098.

18. Ашмарин И.П., Каразеева Е.П., Лелеков Т.В. Эффективность ультрамалых доз эндогенных биорегуляторов и иммуноактивных соединений. Микробиология. - 2005. - № 3. - С. 109116.

19. Gudkov S.V., Lyakhov G.A., Pustovoy V.I., Shcherbakov I.A. Influence of Mechanical Effects on the Hydrogen Peroxide Concentration in Aqueous Solutions. Physics of Wave Phenomena. - 2019. Vol.27, №2. - P.141-144.

20. Bunkin N.F., Shkirin A.V., Penkov N.V., Chirikov S.N., Ignatiev P.S., Kozlov V.A. The physical nature of mesoscopic inhomogeneities in highly diluted aqueous suspensions of protein particles. Physics of Wave Phenomena. - 2019. - Vol.27, №2. - P.102-112.

21. Chikramane P.S., Kalita D., Suresh A.K., Kane S.G., Bellare J.R. Why extreme dilutions reach non-zero asymptotes: a nanoparticulate hypothesis based on froth flotation. Langmuir. - 2012. - Vol.28, №45. - P.15864-15875. doi: 10.1021/la303477s.

22. Don E., Farafonova O., Pokhil S., Barykina D., Nikiforova M., Shulga D., Borshcheva A., Tarasov S., Ermolaeva T., Epstein 0 . Use of piezoelectric immunosensors for detection of interferon-gamma interaction with specific antibodies in the presence of released-active forms of antibodies to interferon-gamma // Sensors. - 2016. - Vol.16, №1. - pii: E96. doi: 10.3390/s16010096.

23. Pschenitza M., Gavrilova E.S., Tarasov S.A., Knopp D., Niessner R., Epstein O.I. Application of a heterogenes immunoassay for the quality control testing of release-active forms of diclofenac // 
International immunopharmacology. - 2014. - Vol.21, Issue 1. - P.225-230.

24. Penkov N. and Fesenko E. Development of Terahertz Time-Domain Spectroscopy for Properties Analysis of Highly Diluted Antibodies // Applied Sciences. - 2020. - V.10(21). - 7736. doi:10.3390/app10217736.

25. Gudkov S.V., Penkov N.V., Baimler I.V., Lyakhov G.A., Pustovoy V.I., Simakin A.V., Sarimov R.M., Scherbakov I.A. Effect of Mechanical Shaking on the Physicochemical Properties of Aqueous Solutions // International Journal of Molecular Sciences. - 2020. - V. 21(21). - 8033. doi:10.3390/ijms21218033.

26. Gorbunov E.A., Nicoll J., Kachaeva E.V., Tarasov S.A., Epstein O.I. Subetta increases phosphorylation of insulin receptor $\beta$-subunit alone and in the presence of insulin. Nutrition \& Diabetes. - 2015. Vol.5(7) - P.e169. doi: 10.1038/nutd.2015.20.

27. Nicoll J., Gorbunov E.A., Tarasov S.A., Epstein O.I. Subetta Treatment Increases Adiponectin Secretion by Mature Human Adipocytes In Vitro. International Journal of Endocrinology. - 2013. - Vol.2013. 925874. doi: 10.1155/2013/925874.

28. Chu X., Agmo A. Sexual incentive motivation in old male rats: The effects of sildenafil and a compound (Impaza) stimulating endothelial NO synthase. Pharmacology, biochemistry, and behavior. - 2008. - Vol.89. - P.209-217.

29. Bailbé D., Philippe E., Gorbunov E., Tarasov S., Epstein O., Portha B. The Novel Oral Drug Subetta Exerts an Antidiabetic Effect in the Diabetic Goto-Kakizaki Rat: Comparison with Rosiglitazone. Journal of Diabetes Research. - 2013. - Vol.13, №1. - P.1-9.

30. Castagne V., Lemaire M., Kheyfets I., Dugina J.L., Sergeeva S.A., Epstein O.I. Antibodies to S100 proteins have anxiolytic-like activity at ultra-low doses in the adult rat. Journal of Pharmacy and Pharmacology. - 2008. - Vol.60, №3. - P.309-316.

31. Kardash E.V., Ertuzun I.A., Khakimova G.R., Kolyadin A.N., Tarasov S.A., Wagner S., Andriambeloson E., Ivashkin V.T., Epstein O.I. Dose-response effect of antibodies to S100 protein and cannabinoid receptor type 1 in released-active form in the light-dark test in mice. Dose-Response: An International Journal. - 2018. - Vol.16, №2. - P.1559325818779752. doi:10.1177/1559325818779752.

32. Don E.S., Emelyanova A.G., Yakovleva N.N., Petrova N.V., Nikiforova M.V., Gorbunov E.A., Tarasov S.A., Morozov S.G., Epstein O.I. Dose-Dependent Antiviral Activity of Released-Active Form of Antibodies to Interferon-Gamma against influenza A/California/07/09(H1N1) in Murine Model. Journal of Medical Virology. - 2017. - Vol.89, №5. - P.759-766. doi: 10.1002/jmv.24717.

33. Rafalsky V., Averyanov A., Bart B., Minina E., Putilovskiy M., Andrianova E., Epstein O. Efficacy and safety of Ergoferon versus oseltamivir in adult outpatients with seasonal influenza virus infection: a multicenter, open-label, randomized trial. International Journal of Infectious Diseases. - 2016. Vol.51. - P.47-55. doi: 10.1016/j.ijid.2016.09.002

34. Mkrtumyan A., Romantsova T., Vorobiev S., Volkova A., Vorokhobina N., Tarasov S., Putilovskiy M., Andrianova E., Epstein O. Efficacy and safety of Subetta add-on therapy in type 1 diabetes mellitus: 
The results of a multicenter, double-blind, placebo-controlled, randomized clinical trial. Diabetes Research and clinical practice. - 2018. - Vol.142. - P.1-9. doi: 10.1016/j.diabres.2018.04.044.

35. Pushkar D., Vinarov A., Spivak L., Kolontarev K., Putilovskiy M., Andrianova E., Epstein O. Efficacy and safety of Afalaza in men with symptomatic benign prostatic hyperplasia at risk of progression: a multicenter, double-blind, placebo-controlled, randomized clinical trial. Central European Journal of Urology. - 2018. - Vol.71. - P.427-435. doi:10.5173/ceju.2018.1803.

36. Никифоров В.В., Руженцова Т.А. Клиническая эффективность и безопасность Эргоферона при гриппе и других острых респираторных вирусных инфекциях: критическая оценка с позиций доказательной медицины. Инфекционные болезни: новости, мнения, обучение. 2019. Т. 8, № 4. С. 84-97.

37. Геппе Н.А., Горелов А.В., Шамшева О.В., Ситников И.Г., Ситникова Е.П., Стешин В.Ю., Мельникова И.М., Черная Н.Л., Вотякова О.И., Эгамова И.Н., Лукашова Л.В., Яковлева Л.В., Коваленко Т.В., Великорецкая М.Д., Кудряшова М.А. Профилактика острых респираторных вирусных инфекций, включая грипп, у детей в период подъема сезонной заболеваемости: результаты международного двойного слепого плацебо-контролируемого рандомизированного клинического исследования. Российский вестник перинатологии и педиатрии. - 2020. - Т.65, №3. - С.109-120. doi:10.21508/1027-4065-2020-65-3-109-120.

38. Pittayanon R, Yuan Y, Bollegala NP, Khanna R, Leontiadis GI, Moayyedi P. Prokinetics for functional dyspepsia. Cochrane Database of Systematic Reviews 2018, Issue 10. Art. No.: CD009431. DOI: 10.1002/14651858.CD009431.pub3.

39. Vladimir T. Ivashkin, Elena A. Poluektova, Alexey B. Glazunov, Mikhail A. Putilovskiy, Oleg I. Epstein. Pathogenetic approach to the treatment of functional disorders of the gastrointestinal tract and their intersection: results of the Russian observation retrospective program COMFORT. BMC. Gastroenterology (2020) 20:2.

40. Самсонов А.А., Лобанова Е.Г., Михеева О.М., Яшина А.В., Аксельрод А.Г. Современные подходы к лечению перекреста функциональных заболеваний желудочно-кишечного тракта. Consilium Medicum, 2017; T.19, №8.2 Гастроэнтерология, 17-26.

\section{Figures}




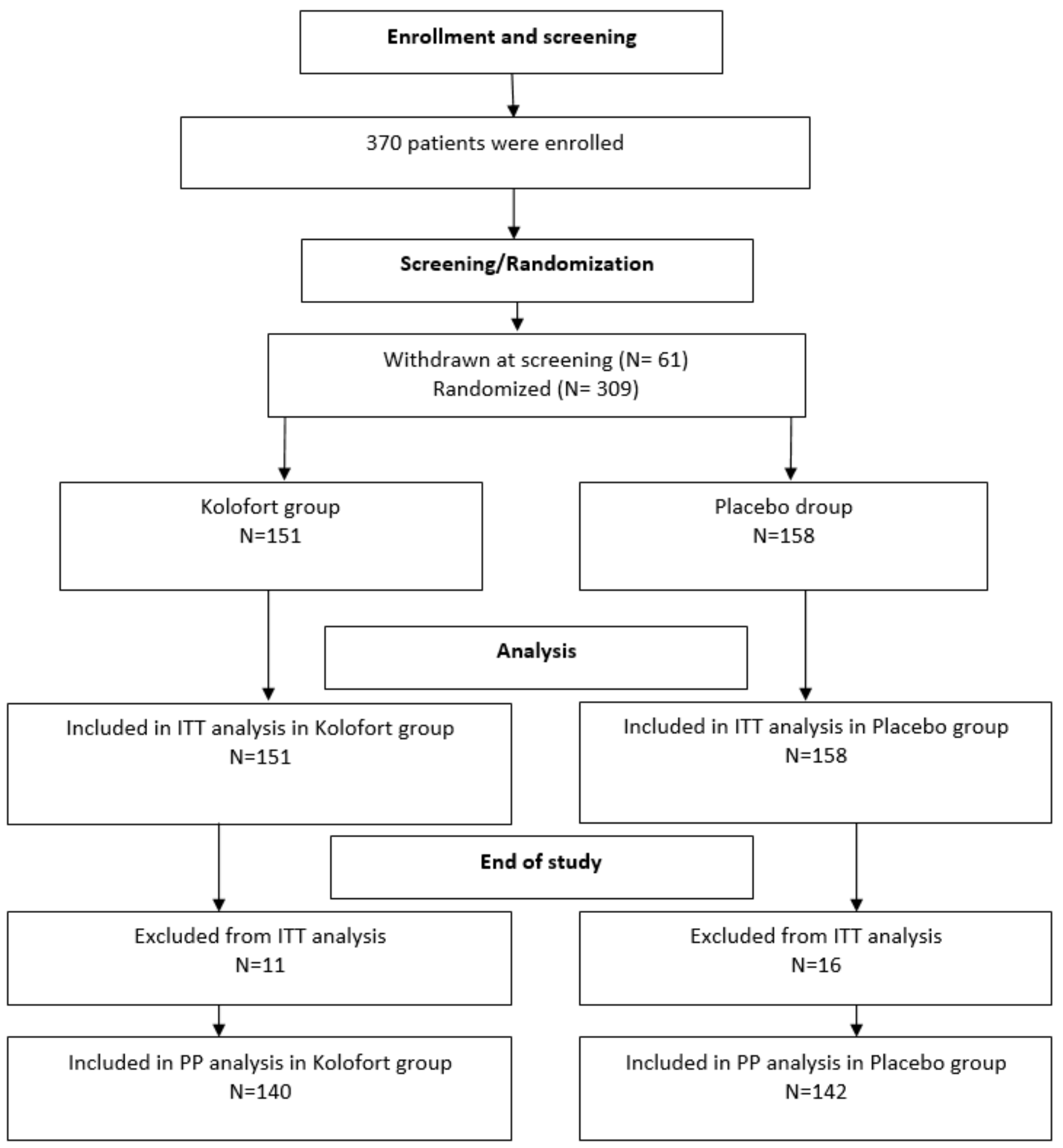

Figure 1

Patient flow chart. 


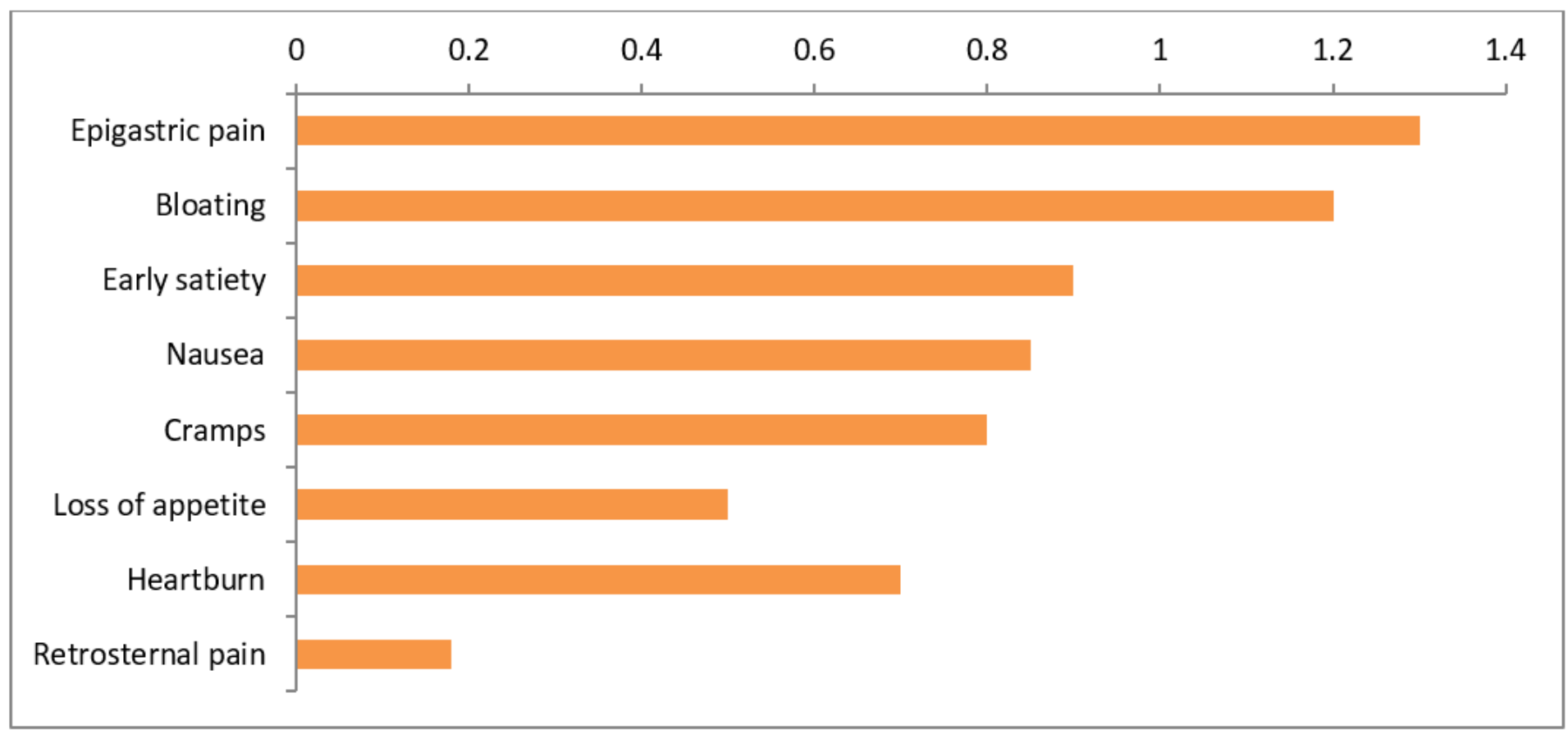

Figure 2

Changes in the severity of FD symptoms according to the GIS sum score in patients with Helicobacter pylori-negative chronic gastritis. 